\title{
PENGARUH KEPUASAN KERJA, LINGKUNGAN KERJA, KEPEMIMPINAN DAN STRES KERJA TERHADAP KINERJA PEGAWAI PADA KANTOR WILAYAH DJP SUMATERA UTARA I
}

\author{
Nurdiana Tanjung \\ Universitas Islam Sumatera Utara \\ nurdiana.tanjung@gmail.com
}

\begin{abstract}
The purpose of this study was to determine and analyze the effect of job satisfaction, work environment, leadership and work stress on employee performance in the North Sumatra DGT Regional Office I. The population in this study was 125 North Sumatra DGT Regional Office employees, with 125 sampling techniques using Slovin as many as 95 people. Based on the analysis results obtained value-t Job satisfaction $=2,680$, while t-table with dk 95 (attached) of 1.65, then $t$ count> t-table thus partially there is a significant influence between job satisfaction on performance, value $t$ work environment $=2.992$, while t-table with dk 95 (attached) is 1.65 then $t$ count $>t$ table thus partially there is a significant influence between the work environment on employee performance, $t$ value of Leadership $=2,141$ while $t$-table with dk 95 (attached) of 1.65 then $t$ arithmetic $>t$ table thus partially there is a significant influence between Leadership on employee performance, $t$ value of work stress $=-1,812$ while $t$-table with dk 95 (attached) of 1.65 then $t$ count $<t$ table thus partially there is no negative effect between work stress on employee performance. F-count value of 14.765 while the value of F-table (attached) with the numerator dk 4 and the denominator $d k 90$ is equal to 2.48 where F-count $>F$ table (14.765> 2.48), it can be stated that together (multiple) there is a positive and significant influence on job satisfaction, work environment, leadership, work stress on employee performance.
\end{abstract}

Keyworld: Job satisfaction, work environment, leadership, work stress and employee performance

ABSTRAK : Tujuan penelitian ini adalah untuk mengetahui dan menganalisis pengaruh kepuasan kerja, lingkungan kerja, kepemimpinan dan stress kerjater hadap kinerja pegawaipada Kantor Wilayah DJP Sumatera Utara I. Populasi dalam penelitian ini adalah pegawai Kantor Wilayah DJP Sumatera Utara I yang berjumlah 125, dengan teknik penarikan sapel mengunakan slovin sebanyak95 orang. Berdasarkan hasil analisis diperoleh Nilai $-t$ Kepuasan kerja = 2,,680 sedangkan t-tabel dengan dk 95 (terlampir) sebesar 1,65 maka thitung > t-tabel dengan demikian secara parsial ada pengaruh yang signifikan antara Kepuasan kerja terhadap kinerja, Nilai $t$ lingkungan kerja= 2,992, sedangkan t-tabel dengan dk 95 (terlampir) sebesar 1,65 maka t hitung $>t$ tabel dengan demikian secara parsial ada pengaruh yang signifikan antara lingkungan kerjaterhadap kinerjapegawai, Nilai $t$ Kepemimpinan= 2,141 sedangkan t-tabel dengan $d k$ 95(terlampir) sebesar 1,65 maka thitung > t tabel dengan demikian secara parsial ada pengaruh yang signifikan antara Kepemimpinan terhadap kinerjapegawai, Nilai $t$ stress kerja $=-1,812$ sedangkan t-tabel dengan dk 95 (terlampir) sebesar 1,65 maka thitung $<t$ tabel dengan demikian secara parsial tidakada pengaruh negatip antara stress kerja terhadap kinerjapegawai.Nilai $F$ hitung sebesar 14,765sedangkan nilai F-tabel (terlampir) dengan dk pembilang 4 dan dk penyebut 90adalah sebesar 2,48 dimana F-hitung > F tabel $(14,765>2,48)$ maka dapat disebutkan bahwa secara bersama-sama (multiple) terdapat pengaruh positif dan signifikan kepuasan kerja, lingkungan Kerja,Kepemimpinan, stress kerja terhadap kinerja pegawai.

Keyworld : Kepuasan kerja, lingkungan kerja, kepemimpinan, stress kerja dan Kinerja Pegawai 


\section{Pendahuluan}

Ukuran kinerja suatu organisasi tidak dapat diukur dari para pelaksana pelayanan, tetapi justru dari penerima layanan. Hal ini dikarenakan kinerja itu pada dasarnya adalah output dan bukan input. Pihak yang dapat merasakan output bukanlah penyelenggara layanan (birokrasi), akan tetapipengguna jasa layanan (masyarakat). Oleh karena itulah dalam pengukuran suatu kinerja mau tidak mau harus melibatkan konsumen yang berasal dari masyarakat pengguna jasa layanan. Untuk mendapatkan kinerja yang baik, maka sumber daya manusia yang ada dalam Kantor Wilayah DJP Sumatera Utara I harus mempunyai kualitas yang baik pula. Jika kualitas sumber daya manusianya tidak baik, maka kinerjanya dalam melaksanakan tugas tidak akan sesuai dengan yang semestinya.

Faktor pertama yang mempengaruhi kinerja pegawai Kantor Wilayah DJP Sumatera Utara I adalah kepuasan kerja. Menurut Rivai (2009:476), kepuasan kerja pada dasarnya merupakan sesuatu yang bersifat individual. Setiap individu memiliki tingkat kepuasan yang berbeda-beda sesuai dengan sistem nilai yang berlaku pada dirinya. Semakin tinggi penilaian terhadap kegiatan dirasakan sesuai dengan keinginan individu, maka semakin tinggi kepuasannya terhadap kegiatan tersebut. Dengan demikian, kepuasan merupakan evaluasi yang menggambarkan seseorang atas perasaan sikapnya senang atau tidak senang, puas atau tidak puas dalam bekerja. Pegawai yang merasa puas atas pekerjaannya dengan senang hati melakukan pekerjaannya dan berupaya untuk terus menerus meningkatkan kemampuan dan keterampilan mereka, sebaliknya pegawai yang merasa tidak puas dengan pekerjaannya cenderung melihat pekerjaan sebagai hal yang menjenuhkan dan membosankan, sehingga mereka akan melakukan pekerjaannya dengan terpaksa dan asal-asalan.Banyak faktor yang mempengaruhi kepuasan kerja. Rivai (2009:478) menjelaskan faktor-faktor yang dapat mempengaruhi kepuasan kerja pegawai pada dasarnya secara praktis dapat dibedakan menjadi dua kelompok, yaitu faktor intrinsik dan faktor ekstrensik. Faktor intrinsik adalah faktor yang berasal dari dalam diri pegawai dan dibawa oleh setiap pegawai sejak mulai bekerja. Penelitian dari R. Zaiful Arief (2016) menjelaskan bahwa kepuasan kerja berpengaruh positif dan signifikan terhadap kinerja pegawai. Penelitian dari Ali Dahie at.al (2016) menyatakan bahwa kepuasan kerja berpengaruh positif dan signifikan terhadap kinerja.

Lingkungan kerja adalah suatu lingkungan dimana para pekerja dapat bekerja secara optimal sehingga dapat menyelesaikan tugas sesuai dengan target yang telah ditetapkan. Lingkungan kerja menurut Sedarmayanti (2013:52) adalah keseluruhan alat perkakas dan bahan yang dihadapi, lingkungan sekitarnya di mana seseorang bekerja, metode kerjanya, serta pengaturan kerjanya baik sebagai perorangan maupun sebagai kelompok.Lingkungan kerja bertujuan agar dalam melaksankaan pekerjaan tercipta suasana yang tentram, nyaman dan damai sehingga dapat meningkatkan kinerja pegawai. Hasil penelitian yang dilakukan oleh Puji Lestari, (2016) menunjukkan bahwa lingkungan kerja berpengaruh positif dan signifikan terhadap kinerja pegawai. Temuan penelitian tersebut memiliki kesamaan dengan penelitian yang dilakukan Asep Saefudin (2014) bahwa lingkungan kerja berpengaruh positif dan signifikan terhadap kinerja pegawai. Berdasarkan pada kedua studi empiris tersebut, disini peneliti ingin membuktikan kembali apakah lingkungan kerja berpengaruh terhadap kinerja pegawai Kantor Wilayah DJP Sumatera Utara I.

Dalam dunia kerja, kepemimpinan berpengaruh kuat terhadap jalannya suatu organisasi dan kelangsungan hidup serta keberlangsungan jalannya suatu organisasi. Kepemimpinan bukan merupakan suatu hal yang bisa disepelekan keberadaannya dalam organisasi, peran kepemimpinan sangat strategis dan penting dalam sebuah organisasi. Salah satu peran kepemimpinan yaitu sebagai penentu keberhasilan dan kelancaran dalam pencapaian tujuan yaitu misi, serta menentukan cara untuk mencapai tujuan suatu organisasi hingga dapat berjalan lancar dan berhasil.

Menurut Robbins (2007:43)menjelaskan stres kerja adalah kondisi yang muncul dari interaksi antara pegawai dengan pekerjaan serta dikarakteristikkan oleh perubahan manusia yang memaksa mereka untuk menyimpang dari fungsi normal mereka. Gejala stres kerja ini dapat dilihatantara lain emosi tidak stabil, perasaan tidak tenang, suka menyendiri, sulit tidur, merokok yang berlebihan, tidak bisa rileks, cemas, tegang, gugup, tekanan darah meningkat, dan mengalami gangguan pencernaan. Stres kerja yang dialami oleh pegawai akan membawa dampak negatif 
terhadap kinerja, artinya pegawai yang memiliki tingkat stres kerja tinggi cendrung memiliki kinerja yang rendah dan pada akhirnya berdampak penurunan kinerja pegawai tersebut. Beberapa studi empiris terdahulu membuktikan bahwa variabel stres kerja memiliki pengaruh yang negatif terhadap kinerja pegawai, diantaranya penelitian dari Azmi (2016), Suranani (2015) dan Wani (2013).

Adaoun Tujuan penelitian ini adalah :

1. Untuk mengetahui dan menganalisispengaruhkepuasankerjaterhada pkinerjapegawaipada Kantor Wilayah DJP Sumatera Utara I.

2. Untuk mengetahui dan menganalisispengaruhlingkungankerjaterhad apkinerjapegawaipada Kantor Wilayah DJP Sumatera Utara I.

3. Untuk mengetahui dan menganalisispengaruhkepemimpinanterhada pkinerjapegawaipada Kantor Wilayah DJP Sumatera Utara I.

4. Untuk mengetahui dan menganalisispengaruhstreskerjaterhadapkine rjapegawaipada Kantor Wilayah DJP Sumatera Utara I.

5. Untuk mengetahui menganalisispengaruh kepuasan lingkungankerja, kepemimpinan dan streskerjaterhadapkinerjapegawaipada Kantor Wilayah DJP Sumatera Utara I.

\section{Metode Penelitian}

\subsection{Lokasi Penelitian}

Lokasi penelitian dilakukan di pada Kantor Wilayah DJP Sumatera Utara I.Jalan Sukamulia No. 17-A, Medan-20151.

\subsection{Populasi dan Sampel}

Populasi dalam penelitian ini adalah pegawai Kantor Pelayanan Pajak Madya Medan yang berjumlah 125 orang. Teknik pengambilan sampel dalam penelitian ini menggunakan Slovin dalam Sekaran dan Bougie (2010:112), berjumlah 95 orang pegawai, setelah perhitungan di atas, penetapan jumlah sampel dalam penelitian ini menggunakan metode stratified random sampling yaitu penarikan sampel berdasarkan pada strata populasi pada setiap bagian, sehingga sampel dalam penelitian ini berjumlah 95 orang pegawai, dengan rincian sebagai berikut :

Tabel 1

Kerangka sampel berdasarkan jabatan

\begin{tabular}{|c|l|c|}
\hline No & Keterangan/Jabatan & $\begin{array}{c}\text { Jumlah } \\
\text { (Orang) }\end{array}$ \\
\hline 1 & Kepala Bidang & 4 \\
\hline 2 & Kepala Seksi & 13 \\
\hline 3 & Penelaah Keberatan & 13 \\
\hline 4 & Fungsional & 21 \\
\hline 5 & Pelaksana & 44 \\
\hline \multicolumn{2}{|c|}{ Total } & 95 \\
\hline
\end{tabular}

Sumber : Kantor Wilayah DJP Sumatera Utara I, 2019

\subsection{Defenisi Operasional}

Terdapat dua variabel dalam penelitian ini, variabel-variabel tersebut adalah Variabel Terikat, yaitu kinerja (Y), Variabel Bebas adalah kepuasan kerja $\left(\mathrm{X}_{1}\right)$, lingkungan kerja $\left(\mathrm{X}_{2}\right)$ dan kepemimpinan $\left(\mathrm{X}_{3}\right)$, stres kerja $\left(\mathrm{X}_{4}\right)$.

Tabel 2

Definisi Operasional Variabel

\begin{tabular}{|c|c|c|c|c|}
\hline No & Defenisi Variabel & $\begin{array}{c}\text { Jenis } \\
\text { Variabel }\end{array}$ & Indikator & $\begin{array}{c}\text { Skala } \\
\text { Pengukuran }\end{array}$ \\
\hline 1. & $\begin{array}{l}\text { Kepuasan kerja adalah seperangkat } \\
\text { perilaku kerja positif yang berakar } \\
\text { pada kesadaran yang kental, } \\
\text { keyakinan yang fundamental, } \\
\text { disertai komitmen yang total pada } \\
\text { paradigma kerja yang integral. } \\
\text { Wibowo (2016:111) }\end{array}$ & $\begin{array}{c}\text { Variabel } \\
\text { bebas }\end{array}$ & $\begin{array}{l}\text { 1) Kesetiaan } \\
\text { 2) Kemampuan } \\
\text { 3) Kejujuran } \\
\text { 4) Kreativitas } \\
\text { 5) Kepemimpinan } \\
\text { 6) Tingkat gaji } \\
\text { 7) Kompensasi } \\
\text { langsung } \\
\text { 8)Lingkungan kerja } \\
\text { Hasibuan (2012:166) }\end{array}$ & $\begin{array}{c}\text { Skala } \\
\text { Ordinal }\end{array}$ \\
\hline 2. & $\begin{array}{l}\text { Lingkungan kerja merupakan segala } \\
\text { situasi yang terbentuk di dalam } \\
\text { organisasi sebagai hasil interaksi } \\
\text { antara antara atasan dengan }\end{array}$ & $\begin{array}{c}\text { Variabel } \\
\text { bebas }\end{array}$ & $\begin{array}{l}\text { 1) Suasana kerja } \\
\text { 2) Hubungan dengan rekan } \\
\text { kerja } \\
\text { 3) } \text { Fasilitas kerja }\end{array}$ & $\begin{array}{c}\text { Skala } \\
\text { Ordinal }\end{array}$ \\
\hline
\end{tabular}




\begin{tabular}{|c|c|c|c|c|}
\hline & $\begin{array}{l}\text { bawahan, dan antara pegawai } \\
\text { dengan pegawai lainnya. } \\
\text { Mangkunegara (2015:183) }\end{array}$ & & $\begin{array}{l}\text { 4) Penerangan } \\
\text { 5) Sirkulasi udara } \\
\text { 6) Kebisingan } \\
\text { 7) Bau tidak sedap } \\
\text { 8) Keamanan } \\
\text { Sedarmayanti (2013:177) }\end{array}$ & \\
\hline 3. & $\begin{array}{l}\text { Kepemimpinan adalah kemampuan } \\
\text { dan keterampilan seseorang yang } \\
\text { menduduki jabatan sebagai } \\
\text { pemimpin satuan kerja untuk } \\
\text { mempengaruhi prilaku orang lain } \\
\text { terutama bawahannya untuk berfikir } \\
\text { dan untuk bertindak sedemikian } \\
\text { rupa sehingga melalui prilaku yang } \\
\text { positif ia memberikan sumbangsih } \\
\text { yang nyata dalam pencapaian tujuan } \\
\text { organisasi. } \\
\text { Dessler }(2015: 224)\end{array}$ & $\begin{array}{c}\text { Variabel } \\
\text { bebas }\end{array}$ & $\begin{array}{l}\text { 1) Jujur } \\
\text { 2) Toleransi } \\
\text { 3) Disiplin } \\
\text { 4) Kerjasama } \\
\text { 5) Kreatif } \\
\text { 6) Mandiri } \\
\text { 7) Rasa ingin tahu } \\
\text { 8) Komunikasi } \\
\text { Sedarmayanti (2013:176) }\end{array}$ & $\begin{array}{l}\text { Skala } \\
\text { Ordinal }\end{array}$ \\
\hline 4. & $\begin{array}{l}\text { Stres kerja adalah suatu kondisi } \\
\text { ketegangan yang mempengaruhi } \\
\text { emosi, proses berpikir, dan kondisi } \\
\text { seseorang. } \\
\text { Hasibuan (2012:154) }\end{array}$ & $\begin{array}{c}\text { Variabel } \\
\text { bebas }\end{array}$ & \begin{tabular}{|ll} 
1) & Kejelasan instruksi \\
2) & Tidakan pilih kasih \\
3) & Kerjasama \\
4) & Ketersediaan sumber daya \\
5) & Beban kerja \\
6) & Pekerjaan \\
& bertentangan \\
7) & Standar kerja \\
8) & Komunikasi \\
9) & Kejelasan tanggung jawab \\
10) & Kesempatan untuk \\
& promosi \\
11) & Evaluasi dari atasan \\
12) & Ketersediaan informasi \\
Dessler (2015:215)
\end{tabular} & $\begin{array}{c}\text { Skala } \\
\text { Ordinal }\end{array}$ \\
\hline 5. & $\begin{array}{l}\text { Kinerja adalah } \\
\text { hasilkerjasecarakualitasdankuantitas } \\
\text { yang dicapaiolehseorang } \\
\text { pegawaidalammelaksanakantugasny } \\
\text { asesuaidengantanggung jawabyang } \\
\text { diberikanpadanya. } \\
\text { Mangkunegara(2015:65) }\end{array}$ & $\begin{array}{c}\text { Variabel } \\
\text { terikat }\end{array}$ & $\begin{array}{ll}\text { 1) Kesetiaan } \\
\text { 2) Hasil Kerja } \\
\text { 3) Kejujuran } \\
\text { 4) Kedisiplinan } \\
\text { 5) Kreativitas } \\
\text { 6) Kerjasama } \\
\text { 7) Kepemimpinan } \\
\text { 8) Kepribadian } \\
\text { 9) Prakarsa } \\
\text { 10) Kecakapan } \\
\text { 11) Tanggungjawab } \\
\text { Hasibuan (2012:133) } \\
\end{array}$ & $\begin{array}{c}\text { Skala } \\
\text { Ordinal }\end{array}$ \\
\hline
\end{tabular}

Sumber : Wibowo (2016), Hasibuan (2012), Mangkunegara (2015), Sedarmayanti (2013), Dessler(2015).

\subsection{Teknik Pengumpulan Data}

Teknik pengumpulan data dilakukan dengan pengumpulan data primer yaitu data yang dikumpulkan dari sumber-sumber asli untuk tujuan tertentu, atau data yang diperoleh dengan survei lapangan yang menggunakan metode pengumpulan data ordinal, yaitu : wawancara, Kuesioner.

\subsection{Teknik Analisa Data}

Teknik analisis data menggunakan validitas dan realibilitas, uji asumsi klasik dengan menggunakan uji Multikolinearitas, Multikolinearitas, Uji Heteroskedastisitas. Pengujian Hipotesis menggunakan uji regresi berganda.

\section{Hasil Dan Pembahasan}

\subsection{Analisis Regresi}

Analisis regresi digunakan untuk menganalisis data hasil penelitian dengan maksud untuk memperoleh gambaran hubungan fungsional antara variabel bebas dengan 
variabel terikat hal ini dengan menggunakan analisis regresi linier berganda
Berdasarkan analisis regresi linier ganda (Multiple) sebagaimana pada lampiran 10 diperoleh koefisien regresi sebagai berikut.

Tabel 2

Koefisien Regresi

\begin{tabular}{|c|c|c|c|c|c|c|}
\hline \multirow{2}{*}{\multicolumn{2}{|c|}{ Model }} & \multicolumn{2}{|c|}{$\begin{array}{l}\text { Unstandardized } \\
\text { Coefficients }\end{array}$} & \multirow{2}{*}{$\begin{array}{l}\text { Standardized } \\
\text { Coefficients } \\
\text { Beta }\end{array}$} & \multirow[t]{2}{*}{$\mathrm{t}$} & \multirow[t]{2}{*}{ Sig. } \\
\hline & & $\mathrm{B}$ & Std. Error & & & \\
\hline \multirow{5}{*}{1} & (Constant) & 23.988 & 1.754 & & 13.673 & .000 \\
\hline & Kepuasan kerja & .138 & .051 & .281 & 2.680 & .009 \\
\hline & Lingkungan kerja & .185 & .062 & .312 & 2.992 & .004 \\
\hline & Kepemimpinan & .499 & .233 & 1.014 & 2.141 & .035 \\
\hline & Stress kerja & -.427 & .234 & -.870 & -1.822 & .072 \\
\hline
\end{tabular}

Berdasarkan Tabel di atas diperoleh koefisien regresi variabel Kepuasan kerja 0,138, lingkungan kerja $=0,185$, Kepemimpinan 0,499, stress kerja -1,822 dengan konstanta 23, 988 maka dapat dituliskan persamaan regresi sebagai berikut.

\section{$Y=23,988+0,138 X_{1}+0,185 X_{2}+0,499-0,427$}

Persamaan di atas memberi gambaran bahwa perubahan rata-rata variabel kinerja pegawai (Y) tergantung dari perubahan variabel Kepuasan kerja $\left(\mathrm{X}_{1}\right)$, lingkungan $\operatorname{Kerja}\left(\mathrm{X}_{2}\right)$. Kepemimpinan dan stress kerja. Artinya apabila kepuasan kerja, lingkungan kerja, Kepemimpinan semakin baikdan stress kerja dikurangi akan diikuti baiknya kinerja pegawai. Perubahan ini merupakan peningkatan apabila bertanda positip dan penurunan atau pengurangan jika bertanda negatif. Hal ini menunjukkan bahwa ada pengaruh positip kepuasan kerja ,lingkungan kerja, Kepemimpinan, stress kerjaterhadap kinerja pegawai. Artinya apabila Kepuasan kerja , lingkungan kerjadan kepemimpinan ditingkatkan akan diikuti peningkatan kinerja pegawai, akan tetapi stress kerja tidak harus ditingkatkan lagi karena berpngaruh negatip maka harus diturunkan.

\subsection{Uji Hipotesis}

Untuk mengetahui pengaruh variabel bebas secara parsial terhadap variabel terikat digunakan uji $\mathrm{t}$, dimana dengan ketentuan : $\mathrm{t}$ hitung $\leq \mathrm{t}$ - tabel ...............tidak ada pengaruh variabel bebas secara tersendiri terhadap variabel terikat, $\mathrm{t}$ - hitung > $>\mathrm{t}$ - tabel ................. ada pengaruh variabel bebas secara tersendiri terhadap variabel terikat. Derajat kebebasan $(\mathrm{dk})=\mathrm{n}-2$ dan Tingkat kepercayaan $\alpha=0,05$.
Berdasarkan tabel di atas diperoleh nilai -t Kepuasan kerja $=2,, 680$ sedangkan $\mathrm{t}$-tabel dengan $\mathrm{dk} 95$ (terlampir) sebesar 1,65 maka thitung $>\mathrm{t}$-tabel dengan demikian secara parsial ada pengaruh yang signifikan antara Kepuasan kerja terhadap kinerja. Selanjutnya nilai $\mathrm{t}$ lingkungan kerja $=2,992$, sedangkan t-tabel dengan $\mathrm{dk} 95$ (terlampir) sebesar 1,65 maka $\mathrm{t}$ hitung $>t$ tabel dengan demikian secara parsial ada pengaruh yang signifikan antara lingkungan kerja terhadap kinerja pegawai.

Nilai t Kepemimpinan $=2,141$ sedangkan ttabel dengan $\mathrm{dk}$ 95(terlampir) sebesar 1,65 maka $t$ hitung $>t$ tabel dengan demikian secara parsial ada pengaruh yang signifikan antara Kepemimpinan terhadap kinerja pegawai.

Nilai $\mathrm{t}$ stress kerja $=-1,812$ sedangkan $\mathrm{t}$ tabel dengan $\mathrm{dk}$ 95(terlampir) sebesar 1,65 maka $t$ hitung $<\mathrm{t}$ tabel dengan demikian secara parsial tidak ada pengaruh negatip antara stress kerja terhadap kinerja pegawai.

Untuk mengetahui pengaruh variabel bebas secara bersama-sama terhadap variabel terikat digunakan uji-F, (Sudjana, 2013:355) dengan rumus:

$$
: F_{\text {hit }}=\frac{J K_{r e g} / k}{J K_{r e s} /(n-k-1)}
$$

Dimana :

$\mathrm{JK}_{\text {reg }}=$ Jumlah kuadrat regresi

$\mathrm{JK}_{\text {reg }}=$ Jumlah kuadrat residu

$\mathrm{n}$ = Jumlah Sampel

$\mathrm{K}=$ Jumlah varians

Jika : F hitung $>\mathrm{F}$ tabel : Hipotesis diterima

F hitung $<F$ tabel : Hipotesis ditolak

Penelitian ini menggunakan tingkat

kepercayaan $95 \%(\alpha=0.05)$

Berdasarkan analisis varians (Anova) pada lampiran 10dengan hasil sebagai berikut. 
Tabel 3

ANOVA

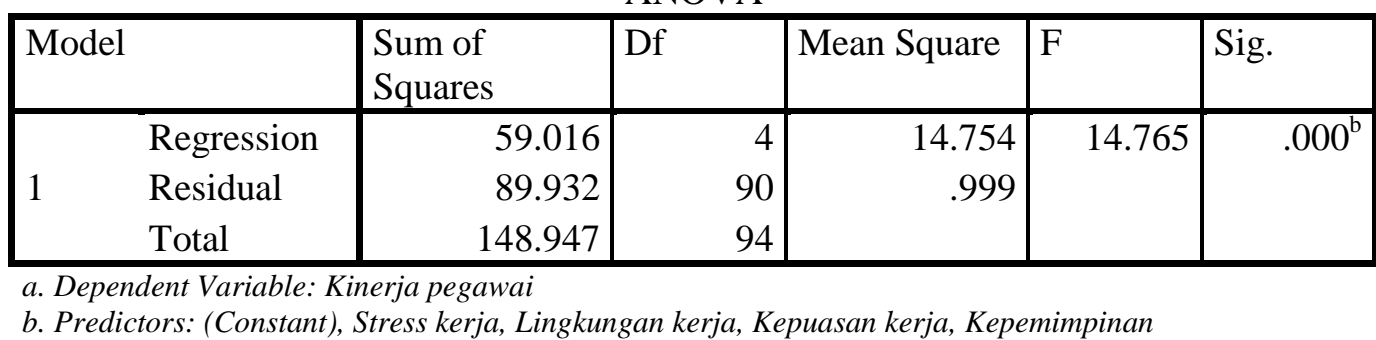

Berdasarkan tabel di atas diketahui nilai Fhitung sebesar 14,765 sedangkan nilai F-tabel (terlampir) dengan $\mathrm{dk}$ pembilang $4 \mathrm{dan} \mathrm{dk}$ penyebut 90adalah sebesar 2,48 dimana Fhitung > F tabel $(14,765>2,48)$ maka dapat disebutkan bahwa secara bersama-sama (multiple) terdapat pengaruh positif dan signifikan kepuasan kerja kerja, lingkungan Kerja,Kepemimpinan, stress kerjaterhadap kinerja pegawai

\section{Pembahasan}

Berdasarkan hasil analisis data Kepuasan kerja pegawai di Kantor Wilayah DJP Sumatera Utara I umumnya kurang puas, lingkungan kerjadi Kantor Wilayah DJP Sumatera Utara I kurang baik, Kepemimpinan juga kurang baik, stress kerja agak banyak dan kinerja pegawai juga kurang tinggi. Kinerja pegawai dapat meningkat apabila Kepuasan kerja semakin maksimal, lingkungan Kerja semakin baik, Kepemimpinan semakin baik dan stress kerja semakin menurun, karena hasil analisis regresi dan pengujian hipotesis diperoleh terdapat pengaruh signifikan Kepuasan kerja, lingkungan kerja, Kepemimpinan, stress kerjasecara bersama-sama terhadap kinerja pegawai. Apabila kepuasan kerja , lingkungan kerja, Kepemimpinan ditingkatkan1\% maka kinerja akan naik $1 \%$. Dan apabila stress kerja diturunkan $1 \%$ maka kinerja akan naik $1 \%$. Besarnya pengaruh Kepuasan kerja Pegawai, kepuasan kerja, Kepemimpinan terhadap kinerja pegawai dapat diketahui melalui uji determinasi (D) dimana $D=R^{2} \times 100 \%$. Hasil analisis pada model summary sebagaimana sebagai berikut:

Tabel 4

Model Summary

\begin{tabular}{|c|c|c|c|c|c|}
\hline Model & $\mathrm{R}$ & R Square & $\begin{array}{l}\text { Adjusted R } \\
\text { Square }\end{array}$ & $\begin{array}{l}\text { Std. Error of } \\
\text { the Estimate }\end{array}$ & $\begin{array}{l}\text { Durbin- } \\
\text { Watson }\end{array}$ \\
\hline 1 & $.629^{\mathrm{a}}$ & .396 & .369 & .99962 & 1.600 \\
\hline
\end{tabular}

b. Dependent Variable: Kinerja pegawai

Berdasarkan tabel5.20diperoleh $\mathrm{R}^{2}=0,396$ maka $\mathrm{D}=0,396 \mathrm{x} 100 \%$ sehingga $\mathrm{D}=39,6 \%$. Dengan demikian pengaruh kepuasan kerja kerja, lingkungan Kerja,Kepemimpinan, stress kerja terhadap kinerja sebesar 39,6\%. sedangkan 60,4\% lagi yang mempengaruhi kinerjaditentukan faktor lain yang tidak diteliti dalam penelitian ini.

\section{Kesimpulan}

1. Terdapat pengaruh kepuasan kerja terhadap kinerja pegawai Kantor Pelayanan Pajak Madya Medan

2. Terdapat pengaruh lingkungan kerja terhadap kinerja pegawai Kantor Pelayanan Pajak Madya Medan
3. Terdapat pengaruh stres kerja terhadap kinerja pegawai Kantor Pelayanan Pajak Madya Medan

4. Terdapat pengaruh kepemimpinan terhadap kinerja pegawai Kantor Pelayanan Pajak Madya Medan

5. Terdapat pengaruh kepuasan kerja, lingkungan kerja, stres kerja, kepemimpinan terhadap kinerja pegawai Kantor Pelayanan Pajak Madya Medan.

\section{DAFTAR PUSTAKA}

Ali, A.Y.S., Dahie, A.M., dan Ali, A.A, (2016),Teacher Motivation and School Performance, the Mediating Effect of Job Satisfaction: Survey from Secondary 
Schools in Mogadishu. International Journal of Education and Social Science Vol. 3 No. 1; January 2016

Arikunto, Suharsismi, (2002),Prosedur Penelitian Suatu Pendekatan Praktek. Jakarta: Rineka Cipta.

AsepSaefudin, (2014), Pengaruh Lingkungan terhadap Kinerja Pegawai di Badan Pendidikan dan Pelatihan Daerah Provinsi Jawa Barat Universitas Pendidikan Indonesia

Azmi, F.S., Shahid, S.A., danAlwi, A, (2016), The Relationship between Job Stress and Front-liners' Job Performance in a Shared Service Center in Malaysia. International Journal of Social Science and Humanity, Vol. 6, No 7

Dessler, Gary (2015), Manajemen Sumber Daya Manusia, Jakarta, Salemba Empat

Handoko T. Hani (2011), Manajemen Personalia dan Sumber Daya Manusia, BPFE, Yogyakarta

Hasibuan Malayu S.P, (2012), Manajemen Sumber Daya Manusia, Edisi Revisi, PT Bumi Aksara, Jakarta

Iqbal, Anwar (2015), Effect of Leadership Style on Employee Performance, Arabian Journal of Business and Management Review, E-ISSN: 2223-5833

Mangkunegara Anwar Prabu (2015), Sumber Daya Manusia Perusahaan, Cetakan keduabelas, Remaja Rosdakarya, Bandung

Mangkuprawira, Sjafri. (2014). Manajemen Sumber Daya Manusia Strategik. Cetakan ketiga, Penerbit Ghalia Indonesia

Marwansyah (2010), Manajemen Sumber Daya Manusia, Alfabeta, Bandung

Mathis, Robeth, John H. Jackson (2009), Human Resource Management, EdisiSepuluh, Diterjemahkanoleh Diana Angelica, SalembaEmpat, Jakarta

M. EsseAbdilahi (2006), Effects of Leadership style on employee performance in Dashen Bank, Addis Ababa, Ethiopia

Nawawi (2011), Manajemen Sumber Daya Manusia: Untuk Bisnis Yang Kompetitif, Gajahmada University Press, Yogyakarta

Puji Lestari, (2016) Pengaruh Lingkungan
Kerja Terhadap Kinerja Pegawai Di Dinas Kependudukan Dan Pencatatan Sipil Kota Bandung.Tesis, Perpustakaan UNPAS

Rivai, Vietzal, dan Ella Sagala (2009), Manajemen Sumber Daya Manusia Untuk Perusahaan. Raja GrafindoPersada Jakarta

Robbins, Stephen P. (2009). Perilaku Organisasi. Edisi kesepuluh. Jakarta: Indeks Kelompok Gramedia.

Rush, Michael danAlthoff, Phillip.(2013). Pengantar Sosiologi Politik. Jakarta: PT. Raja Grafindo Persada

R. Zaiful Arief, (2016), Pengaruh Kepuasan Kerjadan Motivasi Terhadap Kinerja Pegawai Kantor Pelayanan Pajak Sampang, Jurnal Pendidikan, [S.1.], v. 8, n. 2, p. 351-366, dec. 2016. ISSN 24609994

Samsudin, Sadili. (2009). Manajemen Sumber Daya Manusia. Bandung: CV. Pustaka Setia.

Sedarmayanti (2013), Manajemen Sumber Daya Manusia, Reformasi Birokrasi dan Manajemen Pegawai Negeri Sipil, PT. Refika Aditama, Bandung

Sekaran,U., dan Bougie (2010), Research Methods for Busines. A Skill Building Approach. Fifth Edition. A John Wiley and Sons, Ltd, Publication.

Siagian, Sondang. (2008), Manajemen Sumber Daya Manusia (cetakan 15). Jakarta: Bumi Aksara

Simanjuntak Bugaran (2009), Konflik Status Dan Kekuasaan Orang Batak Toba, Yayasan Obor Indonesia, Jakarta

Sugiyono. (2009). Metode Penelitian Kuantitatif dan Kualitatif dan R \& D. Bandung :Alfabeta

Suranani, F. (2015), Role conflict and stress effect on the performance of employees working in public works department. The International Journal of Engineering And Science (IJES), Volume 4 Issue 6 PP.01-10

Thoha, Miftah. (2011). Birokrasi Indonesia Dalam Era Globalisasi, Pusdiklat Pegawai Depdiknas, Sawangan, Bogor

Wibowo (2016), Manajemen Kinerja, Edisi Kelima, PT.Rajagrafindo Persada Jakarta. 